\title{
METODE DALAM PROSES PEMBELAJARAN: Studi tentang Ragam dan Implementasinya
}

\author{
Oleh: Kamsinah*
}

\begin{abstract}
The study of various methods in the teaching process that supporting the educator to prepare and set achievement process of teaching goal. Teacher, mentor, and facilitator constitute one of the important factors to lead the learners to get better understanding about the material with various ways which have been decided systematically in situation and certain condition. Concerning with, it needs comprehensive understanding to set the use of a method in the teaching process. How variety with method implementation in the teaching process becomes explanation focus in this writing. The understanding and various methods from educational experts with its implementation description presented by hoping can be used to increase the learners' interest, in order to make easy the goal achievement suitable with subject matter in the teaching process. However, a material is good and complicated, but it is not supported by appropriate strategy, method, or technique in its presenting will pass by without impression.
\end{abstract}

KEYWORDS: Metode, proses pembelajaran, implementasi

MASALAH pendidikan dan pengajaran merupakan persoalan yang cukup kompleks, sebab banyak hal yang ikut mempengaruhinya. Salah satu faktor itu di antaranya adalah guru. Guru merupakan komponen pembelajaran yang memegang peranan penting dan utama, karena keberhasilan proses pembelajaran sangat ditentukan oleh faktor guru. Tugas guru adalah menyampaikan materi pelajaran kepada peserta didik dengan menggunakan cara atau metode dalam proses pembelajaran yang dilaksanakan. Keberhasilan guru menyampaikan materi kepada peserta didiknya sangat tergantung pada metode yang digunakan. Minimnya metode yang digunakan membawa akibat terhadap pesan yang diberikan oleh guru.

*Magister Pendidikan Islam ini adalah lulusan Program Pascasarjana Universitas Islam Negeri (UIN) Alauddin Makassar yang sedang menyelesaikan program doktor pada bidang dan almamater yang sama. Ia adalah dosen tetap Fakultas Tarbiyah dan Keguruan UIN Alauddin Makassar. 
Secara umum, metode pendidikan adalah cara yang dapat ditempuh dalam memudahkan pencapaian tujuan pendidikan. Perlu diingat, bahwa metode sangat terkait dengan pendekatan yang digunakan.

Dari sekian banyak metode pendidikan yang ditawarkan oleh beberapa pakar pendidikan, tidak semuanya dapat diaplikasikan pada setiap pelajaran. Oleh karena itu, hendaknya setiap pendidik terlebih dahulu dapat mempertimbangkan metode apa yang tepat untuk digunakan, yang dapat mempengaruhi hasil belajar ke arah yang lebih baik dan relevan dengan materi pelajaran yang akan disampaikan. Di samping itu, penggunaan metode yang bervariasi juga menjadi pertimbangan bagi setiap guru, untuk meningkatkan minat belajar anak.

Perkembangan metode pendidikan diukur dari seberapa modern media yang digunakan oleh setiap pendidik dalam mengaplikasikan metode yang ada. Karena pada dasarnya metode-metode tersebut tidak ada yang tertinggal pada setiap periode. Di samping diakui banyak metode yang lahir sesuai dengan perkembangan pemikiran dan kebutuhan kemajuan zaman. Dengan begitu, untuk memudahkan pencapaian tujuan pendidikan, maka guru perlu mengetahui, memahami, dan mengaplikasikan berbagai metode dalam proses pembelajaran.

Berdasarkan latar belakang di atas, dapat diketahui bahwa untuk mencapai tujuan pembelajaran tidaklah mudah, harus ditunjang oleh penggunaan metode atau cara penyajian materi yang bervariasi sehingga dapat meningkatkan minat belajar peserta didik. Oleh karena itu, penulis mencoba merumuskan beberapa permasalahan yang akan menjadi bahan kajian selanjutnya, yaitu: apa yang dimaksud metode dan proses pembelajaran, dan bagaimana metode dalam proses pembelajaran.

Permasalahan di atas diharapkan dapat mengungkap dan membantu para peserta didik umumnya dan pendidik khususnya dalam mempermudah pencapaian tujuan pendidikan melalui proses pembelajaran.

\section{PENGERTIAN METODE DAN PROSES PEMBELAJARAN}

\section{Pengertian Metode}

Secara etimologis, istilah metode berasal dari bahasa Yunani, yaitu metodos. Kata ini terdiri dari dua suku kata, yaitu "metha" yang berarti melalui atau melewati dan "hodos" yang berarti jalan atau cara. Metode berarti jalan yang dilalui untuk mencapai tujuan. ${ }^{1}$ Dalam bahasa Arab, metode disebut thariqat2; dalam Kamus Besar Bahasa Indonesia, metode adalah: "cara yang teratur dan terpikir baik-baik untuk mencapai maksud". ${ }^{3}$ Dengan begitu, dapat dipahami bahwa metode berarti suatu 
cara yang harus dilalui untuk menyajikan bahan pelajaran agar tecapai tujuan pengajaran.

Oleh karena itu, metode mengajar dapat berarti alat yang merupakan perangkat atau bagian dari suatu strategi pengajaran. Strategi pengajaran juga merupakan suatu pendekatan yang digunakan untuk mencapai tujuan. Jadi, cakupan strategi lebih luas dibanding metode atau teknik dalam pengajaran. ${ }^{4}$

Sejalan dengan itu, Ahmad Tafsir menyatakan bahwa dari literatur ilmu pendidikan, khususnya ilmu pengajaran dapat ditemukan berbagai metode mengajar. Sementara metode mendidik, selain dengan cara mengajar, tidak terlalu banyak dibahas oleh para ahli. Sebabnya, mungkin metode mengajar lebih jelas, lebih tegas, objektif, bahkan universal; sedangkan metode mendidik selain mengajar lebih subjektif, kurang jelas, kurang tegas, lebih bersifat seni daripada sebagai sains. ${ }^{5}$

Artinya, yang akan dibicarakan pada uraian-uraian selanjutnya adalah metode mengajar, walaupun tidak dapat dipungkiri bahwa metode mengajar itu beragam adanya. Dengan kata lain, metode merupakan cara yang terstruktur dan teruji secara matang untuk mencapai maksud dan tujuan. Kaitannya dengan mengajar tentu lebih terukur dan sifatnya formal untuk sampai pada target yang telah ditetapkan.

Dengan demikian, perlu diingat bahwa untuk memudahkan pencapaian tujuan pendidikan, maka guru harus mengetahui, memahami, dan mengaplikasikan berbagai metode dalam proses pembelajaran.

\section{Pengertian Proses Pembelajaran}

Menurut Muhammad Ali, para ahli pendidikan berbeda pendapat dalam merumuskan definisi pembelajaran yang disebabkan adanya perbedaan pada faktor: mengidentifikasi data, menafsirkan fakta, penggunaan terminologi dan konotasi istilah, serta penekanan terhadap aspek-aspek tertentu. ${ }^{6}$ Dalam proses pembelajaran terdapat dua aktivitas yang berlangsung, belajar dan mengajar.

Bilamana pengertian tersebut ditujukan untuk penguasaan bahan pelajaran semata, maka akan memberi makna yang terlalu sempit dan bersifat intelektualistis. Para ahli berpendapat bahwa belajar bukan sekedar penguasaan bahan, tetapi terjadinya perubahan tingkah laku anak sehingga terbentuk suatu kepribadian yang baik. ${ }^{7}$

Perbedaan definisi belajar disebabkan oleh adanya perbedaan sudut pandang dan disiplin ilmu para pakar pendidikan. Oleh karena itu, beberapa definisi belajar dapat dikemukakan sebagai berikut. 
Sebagaimana uraian Oemar Hamalik bahwa menurut teori ilmu jiwa daya, belajar ialah usaha melatih daya-daya agar berkembang sehingga dapat berpikir, mengingat, dan sebagainya. Menurut teori ini, jiwa manusia terdiri dari berbagai daya seperti; daya berpikir, mengingat, merasa, mengenal, kemauan, dan sebagainya. Daya-daya tersebut berkembang dan berfungsi bila dilatih dengan bahan-bahan dan cara-cara tertentu.

Menurut teori ilmu jiwa asosiasi, belajar berarti membentuk sejumlah hubungan stimulus dengan respon dan melatih sejumlah hubungan tersebut agar bertalian dengan erat. Pandangan teori ini dilatarbelakangi oleh pendapat bahwa jiwa manusia terdiri atas berbagai asosiasi berbagai tanggapan yang masuk ke dalam jiwa. Asosiasi tersebut dapat terbentuk karena adanya hubungan antara stimulus dan respon.

Menurut teori ilmu jiwa Gestalt, belajar ialah mengalami, berbuat, bereaksi dan berpikir secara kritis. Pandangan ini dilatar belakangi oleh anggapan bahwa jiwa manusia bukan terdiri dari elemen-elemen tetapi merupakan satu sistem yang bulat dan berstruktur. Jiwa manusia hidup dan di dalamnya terdapat prinsip aktif di mana individu selalu cenderung untuk beraktifitas dan berinteraksi dengan lingkungannya. ${ }^{8}$

Dari beberapa pendapat di atas, tampaknya terdapat beberapa perbedaan istilah tentang belajar, tetapi pada hakekatnya ada kesamaan pandangan tentang bagaimana usaha mengaktifkan berpikir, bereaksi, dan berbuat terhadap suatu objek yang dipelajari sehingga timbul suatu pengalaman baru dalam diri seseorang.

Sebagai tambahan, diharapkan agar kemampuan anak dapat dikembangkan secara optimal dengan melatihkan berbagai model cara belajar. Cara belajar induktif melatih anak untuk menjadi manusia kreatif dan inovatif. Sedangkan cara belajar deduktif melatih anak menjadi logis dan kritis. Cara belajar ini berdampak mengaktifkan anak dalam melatih kemandirian dan mengetahui hakekat belajar yang sebenarnya. Berpikir kritis dan kreatif dapat meningkatkan berbagai kemampuan intelektual anak. Sikap kritis sangat dibutuhkan untuk mencari kebenaran fakta, teori, dan konsep berdasarkan pembuktian yang logis. Selain itu, berpikir kritis sangat diperlukan manusia untuk memecahkan berbagai masalah dalam kehidupan. Hanya orang kritislah yang segera dapat memecahkan masalah yang dihadapi dalam kehidupan. Guru dalam proses pembelajaran harus dapat menciptakan iklim belajar yang menantang anak untuk berpikir kritis dan logis.

Sedangkan mengajar adalah suatu proses yang kompleks yang tidak hanya sekedar menyampaikan informasi oleh guru kepada peserta didik, tetapi banyak hal dan kegiatan yang harus dipertimbangkan dan dilaku- 
kan. Oleh karena itu, rumusan pengertian mengajar tidak sesederhana yang dibayangkan.

S. Nasution merumuskan pengertian mengajar sebagai berikut: pertama, mengajar ialah menanamkan pengetahuan kepada murid; kedua, mengajar ialah menyampaikan kebudayaan kepada anak; dan ketiga, mengajar ialah aktivitas mengorganisasi atau mengatur lingkungan dengan sebaik-baiknya dan menghubungkan dengan anak sehingga terjadi proses belajar-mengajar. ${ }^{9}$

Berdasarkan definisi mengajar yang telah dikemukakan di atas dapat dipahami bahwa: 1) mengajar bertujuan agar anak dapat menguasai pengetahuan yang diberikan oleh guru, dimana anak hanya bersifat pasif sedangkan guru bersifat aktif (teacher centered); 2) sama halnya dengan definisi pertama dimaksudkan agar anak dapat mengenal kebudayaan bangsa dan dunia, bahkan agar anak tidak hanya sekedar mengenal kebudayaan, tetapi turut menciptakan kebudayaan yang baru sesuai dengan tuntutan zaman yang selalu berubah; 3) berbeda dengan yang pertama dan yang kedua, yakni suatu usaha guru untuk mengatur dan mengorganisasi lingkungan sehingga dapat tercipta suatu situasi dan kondisi yang baik bagi siswa dalam belajar. Dengan demikian, anak dapat belajar secara aktif dan guru berperan sebagai pembimbing dan pengorganisasi terhadap kondisi belajar anak (pupil centered) dan peran guru sebagai manager of learning.

Selanjutnya Hasibuan dan Moedjiono memberikan definisi mengajar sebagai penciptaan sistem lingkungan yang memungkinkan terjadinya proses belajar. ${ }^{10}$

Dengan melihat pengertian dan defenisi pembelajaran di atas, dapat disimpulkan bahwa proses pembelajaran ialah terjadinya saling mempengaruhi antara komponen tujuan, guru, siswa, materi, jenis kegiatan yang dilakukan, dan sarana pembelajaran dalam suatu sistem lingkungan.

\section{Implementasi Metode dalam Proses Pembelajaran}

Pada saat mengajar, guru yang tidak mengenal metode mengajar jangan diharap dapat melaksanakan proses pembelajaran sebaik-baiknya. Untuk mendorong keberhasilan guru dalam proses pembelajaran perlu diketahui bahwa setiap metode pembelajaran yang digunakan bertalian dengan tujuan belajar yang ingin dicapai. Tujuan untuk mendidik anak agar sanggup memecahkan masalah-masalah dalam belajarnya memerlukan metode yang lain. Oleh karena itu, untuk mendorong keberhasilan guru dalam proses pembelajaran, guru seharusnya mengerti akan fungsi, dan langkah-langkah pelaksanaan metode mengajar. 
Metode-metode mengajar, yang direncanakan akan digunakan dalam memaparkan setiap pokok bahasan yang telah ditetapkan, hendaknya dicantumkan dalam perencanaan pembelajaran program satu semester. Hal ini penting dilakukan mengingat faktor metode menempati posisi kedua terpenting setelah tujuan dari sederetan komponen-komponen pembelajaran: tujuan, metode, materi, dan evaluasi. ${ }^{11}$

Oleh karena itu, seorang guru dituntut agar cermat memilih dan menetapkan metode apa yang tepat digunakan untuk menyampaikan materi pelajaran kepada peserta didik. Sebab, dalam proses pembelajaran (PBM) dikenal ada beberapa macam metode, antara lain: metode ceramah, diskusi, tanya jawab, demonstrasi dan lain sebagainya. Semua metode tersebut dapat diaplikasikan dalam proses pembelajaran.

Seiring dengan itu, Tayar Yusuf dan Syaiful mengatakan bahwa ada beberapa faktor yang perlu diperhatikan dalam memilih dan mengaplikasikan sebuah metode pengajaran: 1) tujuan yang hendak dicapai, 2) kemampuan guru, 3) anak didik, 4) situasi dan kondisi pengajaran di mana berlangsung, 5) fasilitas yang tersedia, 6) waktu yang tersedia, dan 7) kebaikan dan kekurangan sebuah metode. ${ }^{12}$

Faktor-faktor tersebut tidak boleh diabaikan, sebab menentukan suatu metode yang tepat dalam pembelajaran sangat berpengaruh pada proses pencapaian tujuan. Terkait dengan itu, guru atau pendidik dituntut memiliki kemampuan professional dalam menetapkan suatu metode sesuai tujuan yang hendak dicapai dengan memperhatikan kondisi psikologis anak atau peserta didik.

Di sisi lain diungkapkan pula bahwa bila topik yang akan dibahas itu luas seperti dalam pengajaran unit, berbagai ragam metode akan perlu digunakan. Biasanya metode mengandung unsur-unsur: a) uraian tentang apa yang akan dipelajari; b) diskusi dan pertukaran pikiran; c) kegiatankegiatan yang menggunakan berbagai alat instruksional, laboratorium, dan lain-lain; d) kegiatan-kegiatan dalam lingkungan sekitar sekolah seperti kunjungan, kerja lapangan, eksplorasi, dan penelitian; e) kegiatan-kegiatan dengan menggunakan berbagai sumber belajar seperti buku perpustakaan, alat audio visual, dan lain-lain; dan f) kegiatan kreatif seperti drama, seni rupa, musik, pekerjaan tangan dan sebagainya. ${ }^{13}$

Unsur-unsur tersebut sangat membantu menguraikan, menjelaskan, mengarahkan, dan menuntun proses pencapaian tujuan yang hendak dicapai dari masing-masing topik bahasan.

Beberapa metode pengajaran yang dikenal secara umum, antara lain adalah: 
1. Metode ceramah, memberikan pengertian dan uraian suatu masalah.

2. Metode diskusi, memecahkan masalah dengan berbagai tanggapan.

3. Metode eksperimen, mencoba mengetahui proses terjadinya suatu masalah.

4. Metode demonstrasi, menggunakan alat peraga untuk memperjelas sebuah masalah.

5. Metode pemberian tugas, dengan cara memberi tugas tertentu secara bebas dan bertanggung jawab.

6. Metode sosiodrama, menunjukkan tingkah laku kehidupan.

7. Metode drill, melatih mengukur daya serap terhadap mata pelajaran

8. Metode kerja kelompok, memecahkan masalah secara bersama-sama dalam jumlah tertentu.

9. Metode Tanya jawab, memecahkan masalah dengan umpan balik.

10. Metode proyek, memecahkan masalah dengan langkah-langkah secara ilmiah, logis, dan sistematis. ${ }^{14}$

Sebagai tambahan, beberapa pakar pendidikan mengemukakan pula sejumlah metode, antara lain:

Pertama, Al-Ghazali mengemukakan beberapa metode alternatif, yaitu:

1. Mujahadah dan Riyadlah Nafiyah (kekuatan dan latihan jiwa). Yaitu mendidik anak dengan cara mengulang-ulangi pengalaman. Hal ini akan meninggalkan kesan yang baik dalam jiwa anak didik dan benar-benar akan menekuninya sehingga terbentu akhlak dan watak dalam dirinya.

2. Pendidik hendaknya menggunakan beberapa metode. Sebab, penggunaan metode yang bervariasi akan membangkitkan motivasi belajar dan menghilangkan kebosanan.

3. Pendidik hendaknya memberikan dorongan dan hukuman. ${ }^{15}$ Memberikan dorongan berupa pujian, penghargaan, dan hadiah kepada anak yang berprestasi akan menjadikan mereka lebih termotivasi. Sedangkan memberikan hukuman hendaknya bersifat mendidik dengan maksud memperbaiki perbuatan yang salah agar tidak menjadi kebiasaan. Pemberian hukuman jasmani disyaratkan bila anak telah sampai usia 10 tahun, dan kalau pun harus melakukan hukuman jasmani hendaknya pukulan tidak melebihi dari 3 kali. Hal ini dimaksudkan untuk memberikan kesempatan bertaubat kepada si terdidik. ${ }^{16}$ Hanya saja poin ketiga menjadi hal dilematis saat ini untuk diterapkan, karena seringkali guru harus berurusan dengan masalah hukum, bahkan dipenjara karena hal tersebut.

Kedua, Ibnu Khaldun mengemukakan pula pendapatnya tentang metode pendidikan, sebagai berikut: 
1. Metode ilmiah yang modern, yaitu menumbuhkan kemampuan memahami ilmu dengan kelancaran berbicara dalam diskusi untuk menghindari verbalisme dalam pelajaran.

2. Metode gradasi (pentahapan) dan pengulangan. Pengetahuan bersifat global bertahap dan terperinci, agar anak memahami permasalahan dan menerima penjelasan sesuai dengan tingkat berpikirnya.

3. Menggunakan media (alat peraga) untuk membantu siswa dalam memahami materi pelajaran.

4. Melakukan karya wisata agar siswa mendapatkan pengalaman belajar secara langsung.

5. Menghindari sistem pengajaran materi dalam bentuk ikhtisar (ringkasan).

6. Memberikan sanksi yang proporsional untuk menumbuhkan motivasi (semangat) belajar siswa. Sanksi yang positif dapat dilakukan dengan memberikan pujian atau hadiah terhadap segala bentuk karya atau tingkah laku positif anak didik. Sementara sanksi negatif berupa hukuman hanya dilakukan bila anak didik berperilaku negatif, tetapi hendaknya dengan pendekatan yang lebih bijaksana.

Ketiga, M. Arifin mengemukakan beberapa metode pendidikan yang dikatakan dapat mewakili metode modern ahli pendidikan dewasa ini, yaitu:

1. Metode situasional dan kondisional dalam pembelajaran.

2. Metode tarhìb dan targhìb, untuk mendorong minat belajar anak didik agar terlepas dari paksaan atau tekanan.

3. Metode kebermaknaan, yaitu menjadikan anak bergairah belajar dengan menyadarkan bahwa pengetahuan itu bermakna dalam hidupnya.

4. Metode dialog, melahirkan sikap saling terbuka antara guru dan murid.

5. Metode pemberian contoh keteladanan yang baik, yang akan mempengaruhi tingkah laku dan sikap mental anak didik.

6. Metode diskusi, memantapkan pengertian dan sikap anak terhadap suatu masalah.

7. Metode induktif dan deduktif.

8. Metode demonstrasi.

9. Metode eksperimen.

10. Metode hadiah dan hukuman. ${ }^{17}$

Kemudian Armai Arief menjelaskan bahwa metode-metode yang dapat dipakai dalam pendidikan dan pengajaran agama Islam, dapat dilihat sebagai berikut: a) metode pembiasaan, b) metode keteladanan, c) metode pemberian ganjaran, d) metode pemberian hukuman, e) metode ceramah, f) metode tanya jawab, g) metode diskusi, h) metode sorogan, i) 
metode Bandongan, j) metode mudzākarah, k) metode kisah 1) metode pemberian tugas, $\mathrm{m}$ ) metode karya wisata, n) metode eksperimen, o) metode drill/latihan, p) metode sosiodrama, q) metode simulasi, r) metode kerja lapangan s) metode demontrasi, dan $\mathrm{t}$ ) metode kerja kelompok. ${ }^{18}$

Selanjutnya lebih rinci Saiful Sagala mengemukakan sejumlah metode mengajar yang mungkin dapat dilakukan oleh guru dengan berbagai langkah, kebaikan dan kelemahannya, antara lain sebagai berikut:

\section{Metode Ceramah}

Metode ceramah adalah sebuah bentuk interaksi melalui penerangan dan penuturan lisan dari guru kepada peserta didik. Dalam kegiatan ini, informasi yang diberikan sering kabur dan samar-samar bagi pendengarnya. Bahkan kemungkinan, jika pendengar ditanya kembali tidak tahu apaapa. Jadi, sebaiknya dalam metode ini guru menggunakan alat-alat bantu seperti gambar, dan audio-visual lainnya.

\section{Metode Tanya-Jawab (Respons)}

Metode tanya-jawab ialah penyampaian pelajaran dengan cara guru mengajukan pertanyaan dan murid menjawab. Dalam metode tanya-jawab terdapat kelemahan dan kelebihan, sehingga seorang guru benar-benar harus memperhatikan kesesuaian materi pelajaran dengan metode yang akan digunakan.

Dalam menggunakan metode tanya-jawab, ada beberapa hal yang harus diperhatikan. Pertama, jenis pertanyaan; kedua, teknik mengajukan pertanyaan; ketiga, memperhatikan syarat-syarat penggunaan metode tanya-jawab sehingga dapat dirumuskan langkah-langkah yang benar; keempat, memperhatikan prinsip-prinsip penggunaan metode tanya jawab, di antaranya prinsip keserasian, integrasi, kebebasan, dan individual. Prinsip-prinsip ini adalah dasar atau landasan yang bisa dipergunakan dalam metode tanya-jawab. Di samping itu, metode tanya-jawab juga bisa dikombinasikan dengan metode lain, seperti metode ceramah, pemberian tugas, diskusi, dan lain-lain.

\section{Metode Diskusi}

Metode diskusi dapat diartikan sebagai jalan untuk memecahkan suatu permasalahan yang memerlukan beberapa jawaban alternatif yang dapat mendekati kebenaran dalam proses pembelajaran (PBM). Metode ini bila digunakan dalam PBM akan dapat merangsang murid untuk berpikir sistematis, logis, kritis, dan bersikap demokratis dalam menyumbangkan pikiran-pikirannya untuk memecahkan sebuah masalah. 
Walaupun begitu, metode ini tidak selalu tepat digunakan pada setiap pelajaran, karena metode ini juga memiliki nilai positif dan negatif. Oleh karena itu, pendidik hendaknya mampu menggunakan metode ini sesuai dengan situasi dan kondisi yang kondusif.

\section{Metode Demonstrasi}

Metode demonstrasi merupakan salah satu metode mengajar dengan menggunakan peragaan untuk memperjelas suatu pengertian atau untuk memperlihatkan bagaimana melakukan sesuatu dengan jalan mendemonstrasikannya terlebih dahulu kepada siswa.

Metode ini dapat menghilangkan verbalisme sehingga siswa akan semakin memahami materi pelajaran. Akan tetapi, ada beberapa hal yang perlu diperhatikan agar metode ini dapat berjalan dengan efektif dan efisien. Dengan kata lain, materi yang didemonstrasikan perlu ditindaklanjuti oleh siswa dalam kehidupan sehari-hari maupun dengan latihan yang kontinu sehingga siswa tidak lupa dengan materi tersebut.

\section{Metode Sosiodrama}

Metode sosiodrama merupakan salah satu bentuk metode belajarmengajar dengan jalan mendramakan atau memerankan sejumlah aksi. Metode sosiodrama bertujuan untuk belajar memahami perasaan orang lain, menggambarkan bagaimana seseorang memecahkan masalah serta melukiskan bagaimana seharusnya seseorang bertindak atau bertingkah laku dalam situasi sosial tertentu.

\section{Metode Karya Wisata}

Metode karya wisata merupakan suatu cara pengajaran yang dilaksanakan dengan jalan mengajak anak didik ke luar kelas untuk dapat memperlihatkan hal-hal atau peristiwa yang ada hubungannya dengan bahan pelajaran. Metode ini lebih menekankan pembinaan pada aspek psikomotorik karena dalam metode ini siswa lebih banyak dituntut keaktifannya dalam setiap kegiatan; sedangkan untuk pembinaan aspek yang lain (kognitif dan afektif) merupakan pendorong untuk tercapainya elaborasi dari teori-teori yang telah didapatkan oleh anak didik.

\section{Metode Kerja Kelompok}

Metode kerja kelompok merupakan salah satu dari sekian banyak metode yang dapat digunakan dalam menyampaikan materi pelajaran kepada anak didik. Metode ini dilakukan dengan cara membagi siswa ke dalam beberapa kelompok baik kelompok kecil maupun kelompok besar. 
Masing-masing kelompok diberikan sejumlah tugas yang harus diselesaikan, sementara guru tetap melakukan pengawasan agar setiap kelompok dapat berjalan sebagaimana mestinya, sehingga tujuan pembelajaran memiliki kelebihan dan kekurangan, demikian halnya dengan metode kerja kelompok. Oleh karena itu, setiap guru hendaknya berusaha semaksimal mungkin untuk memilih metode mana yang paling tepat untuk digunakan dalam sebuah proses pembelajaran.

\section{Metode Latihan}

Metode latihan adalah metode dalam menyampaikan pelajaran dengan melaksanakan latihan secara terus sampai anak didik memiliki ketangkasan yang diharapkan. Metode ini juga merupakan salah satu dari berbagai macam metode yang banyak digunakan oleh para pendidk dalam proses pembelajaran agar tujuan pembelajaran tercapai.

Di sini dituntut peran seorang pendidik yang harus siap terlebih dahulu sebelum memberikan latihan, baik secara teori maupun praktek. Sebaiknya latihan tersebut tidak dilakukan secara spontanitas, sehingga dapat melihat kemajuan setiap anak didik dari segi daya tangkap, keterampilan dan ketepatan berpikir.

\section{Metode Pemberian Tugas}

Metode pemberian tugas merupakan salah satu cara dalam penyajian bahan pelajaran kepada siswa. Guru memberikan sejumlah tugas kepada murid-muridnya untuk mempelajari sesuatu, kemudian mempertanggungjawabkannya.

Metode ini diberikan dalam berbagai kegiatan belajar dari semua mata pelajaran. Namun, tidak berarti setiap kali proses pembelajaran harus menggunakan metode ini. Oleh karena itu, dibutuhkan profesionalisme guru dalam mengaplikasikan metode pemberian tugas yang sesuai dengan situasi dan kondisi yang kondusif.

\section{Metode Eksperimen}

Metode eksperimen merupakan suatu metode dimana murid melakukan pekerjaan akademis dalam mata pelajaran tertentu dengan menggunakan media laboratorium. Penggunaan metode ini hendaknya mendapat perhatian serius dari guru, sebab metode ini memiliki kelemahankelemahan di samping kelebihan-kelebihannya sebagaimana metodemetode lain. Oleh karena itu, kejelian seorang guru dalam memilih metode eksperimen pada proses pembelajaran sangat diperlukan agar tujuan pembelajaran dapat tercapai sebagaimana yang diinginkan. ${ }^{19}$ 
Dari sejumlah metode yang telah diuraikan di atas, dapat ditegaskan bahwa metode mengajar adalah cara yang digunakan oleh guru dalam mengorganisasikan kelas pada umumnya atau dalam menyajikan bahan pelajaran pada khususnya. Metode pembelajaran ini menghendaki peserta didik untuk berlatih mengadakan observasi yang sistematis, membuat catatan, dan membuat laporan tertulis. Mereka juga dapat belajar menggunakan berbagai alat audio visual, menggunakan perpustakaan, mengadakan wawancara dengan menggunakan tape recorder, dan meng-gunakan kamera untuk melengkapi observasi dan laporannya.

\section{PENUTUP}

Sebagai akhir dari tulisan ini, telah dikemukakan terdahulu bahwa metode adalah cara yang digunakan untuk mengimplementasikan rencana yang sudah disusun dalam kegiatan nyata agar tujuan yang telah disusun tercapai secara optimal. Ini berarti, metode digunakan untuk merealisasikan strategi yang telah ditetapkan.

Berbagai bentuk metode telah dikemukakan oleh para pakar pendidikan, seperti: metode ceramah, tanya jawab, diskusi, sorogan, bandongan, mudzakarah, kisah, pemberian tugas, karya wisata, eksperimen, drill/latihan, sosiodrama, simulasi, kerja lapangan, demonstrasi, dan kerja kelompok.

Meskipun tampak ada perbedaan di antara para pakar tentang bentuk-bentuk metode tersebut, tetapi perlu ditegaskan bahwa mereka umumnya menandaskan, metode dalam rangkaian sistem pembelajaran memegang peran yang sangat penting. Keberhasilan implementasi strategi pembelajaran sangat tergantung pada cara guru atau pendidik menggunakan metode pembelajaran, karena suatu strategi pembelajaran hanya mungkin diimplementasikan melalui penggunaan metode pembelajaran.

\section{CATATAN AKHIR:}

1. M. Arifin, Ilmu Pendidikan Islam, cet. V, Jakarta: Bumi aksara, 1996, h. 61.

2. A. W. Munawwir, Kamus Al-Munawwir Arab-Indonesia Terlengkap, Surabaya: Pustaka Proressif, 1997, h. 849.

3. Departemen Pendidikan dan Kebudayaan, Kamus Besar Bahasa Indonesia, ed. II, cet. IV, Jakarta: Balai Pustaka, 1995, h. 652.

4. Basiruddin Usman, Metodologi Pembelajaran Agama Islam, cet. I, Jakarta: Ciputat Pers, 2002, h. 22

5. Ahmad Tafsir, Ilmu Pendidikan dalam Persfektif Islam, cet. IV, Bandung: PT Remaja Rosdakarya Offset, 2004, h. 131.

6. Muhammad Ali, Guru dalam Proses Pembelajaran, Bandung: Sinar Baru, 1984, h. 2. 
7. Basiruddin Usman, Metodologi Pembelajaran Agama Islam, h. 21.

8. Oemar Hamalik, Belajar dan Kesulitan-Kesulitan Belajar, Bandung: Tarsito, 1983, h. 23.

9. S. Nasution, Berbagai Pendekatan dalam Proses Pembelajaran, Jakarta: Bina Aksara, 1982, h. 8

10. Hasibuan dan Moedjiono, Proses Pembelajaran, Bandung: Remaja Rosdakarya, 1986, h. 10

11. Armai Arief, Pengantar Ilmu Dan Metodologi Pendidikan Islam, cet. I, Jakarta: Ciputat Pers, 2002, h. 109.

12. Tayar Yusuf dan Syaiful Anwar, Metodologi Pengajaran Agama dan Bahasa Arab, cet. I, Jakarta: PT. RajaGrafindo Persada, 1995, h. 7-10.

13. Syaiful Sagala, Konsep dan Makna Pembelajaran: untuk Membantu Memecahkan Problematika Belajar dan Mengajar, cet. IV, Bandung: CV. AFABETA, 2006, h. 168-169.

14. Zakiah Darajat, dkk., Metodik Khusus Pengajaran Agama Islam, cet. VI, Jakarta: 1995, h. 289-312.

15. Ali Al-Jumbulati, Perbandingan Pendidikan Islam, cet. I, Jakarta: PT. Rineka Cipta, 1994, h. 160.

16. M. Athiyah Al-Absyari, Dasar-Dasar Pokok Pendidikan Islam, cet. VII, Jakarta: Bulan Bintang, 1993, h. 153.

17. M. Arifin, Ilmu Pendidikan Islam, h. 217.

18. Armai Arief, Pengantar Ilmu Dan Metodologi Pendidikan Islam, h. 110-195.

19. Syaiful Sagala, Konsep dan Makna Pembelajaran: Untuk Membantu Memecahkan Problematika Belajar dan Mengajar, h. 201-220. Lihat pula Armai Arief, Pengantar Ilmu Dan Metodologi Pendidikan Islam, h. 135-200.

\section{DAFTAR PUSTAKA:}

Al-Absyari, M. Athiyah, Dasar-dasar Pokok Pendidikan Islam, cet. VII, Jakarta: Bulan Bintang, 1993.

Ali, Muhammad, Guru dalam Proses Pembelajaran, Bandung: Sinar Baru, 1984.

Arief, Armai, Pengantar Ilmu Dan Metodologi Pendidikan Islam. cet. I, Jakarta: Ciputat Pers, 2002.

Arifin, M., Ilmu Pendidikan Islam, Cet. V, Jakarta: Bumi aksara, 1996.

Daradjat, Zakiah, dkk., Metodik Khusus Pengajaran Agama Islam, Jakarta: 1995.

Departemen Pendidikan dan Kebudayaan, Kamus Besar Bahasa Indonesia, edisi II, cet. IV, Jakarta: Balai Pustaka, 1995.

Hamalik, Oemar, Belajar dan Kesulitan-Kesulitan Belajar, Bandung: Tarsito, 1983.

Hasibuan dan Moedjiono, Proses Pembelajaran, Bandung: Remaja Rosdakarya, 1986.

Al-Jumbulati, Ali, Perbandingan Pendidikan Islam, cet. I, Jakarta: PT. Rineka Cipta, 1994.

Munawwir, A.W., Kamus Al-Munawwir Arab-Indonesia Terlengkap, Surabaya: Pustaka Progressif, 1997.

Nasution, S., Berbagai Pendekatan dalam Proses Pembelajaran, Jakarta: Bina Aksara, 1982. 
Sagala, Syaiful, Konsep dan Makna Pembelajaran: Untuk Membantu Memecahkan Problematika Belajar dan Mengajar, cet. IV, Bandung: CV. AFABETA, 2006.

Tafsir, Ahmad, Ilmu Pendidikan Dalam Persfektif Islam, cet. IV, Bandung: PT. Remaja Rosdakarya Offset, 2004.

Usman, Basiruddin, Metodologi Pembelajaran Agama Islam, cet. I, Jakarta: Ciputat Pers, 2002.

Yusuf, Tayar dan Syaiful Anwar, Metodologi Pengajaran Agama dan Bahasa Arab, cet. I, Jakarta: PT. RajaGrafindo Persada, 1995. 